(e.g., "A Proposed Planning Process for ACRL," September 1984).

\section{Manuscript}

Authors should submit two copies, doublespaced, following either the Chicago Manual of Style or Turabian.

The preferred typewriter elements are: Courier 10, Prestige Elite 12, or Letter Gothic 12.

The deadline for receipt of editorial copy is approximately the 26th of each month, for inclusion in the issue of the second month following.

\section{Requests for Donations}

$C \& R L$ News may occasionally print requests for the donation of books or materials to libraries, especially foreign libraries, which have suffered extensive loss through fire, hurricane, or other natural disaster. Other libraries soliciting contributions for other reasons will be referred to the rates for classified advertising in $C \mho R L N e w s$.

Editor's Note: These guidelines were adopted by the C\&RL News Editorial Board at the Denver Midwinter Meeting on January 25, 1982.

\title{
Chapter visits
}

\section{The ACRL Executive Director visits the Minnesota and}

\author{
Illinois chapters.
}

\begin{abstract}
M innesota, November 1. A brisk fall day, clear and bright, greeted me in Minnesota. Driving to Northfield for the Minnesota Chapter meeting with Peg Johnson gave me the chance to meet our new Audiovisual Committee chair and see some suburban countryside. The Concert Hall on Carleton College's campus was the setting for the meeting, which was attended by over 60 academic and research librarians.

The day-long program began with my talk, entitled "Eight Possible Things Before the Main Speaker," in which I described ACRL, its physical setting, its relation to ALA, a who's who of the staff and a description of key staff activities, and how to participate in the Association at a variety of levels.

Beverly Lynch, president-elect of ALA, gave the keynote speech and addressed the role of the librarian as related to the academic environment. Emphasizing the Naisbett theme of decentralization, Lynch suggested that ALA will be increasing its outreach activities to involve members. She urged librarians in academic institutions to become aware of the environment within their institutions, to consider the problems facing the administration as the key problems for them also, and to contrib-
\end{abstract}

ute a unique viewpoint to their solution. She also emphasized that they need to keep abreast of the whole field of higher education - the external environment of the institution-and to increase their attention to such matters as information policy, access to information, the cost of information retrieval, new skills needed by library staff and users, and the principles of learning.

Lynch reviewed some of her earlier work on the relationship of the library to other organizations, characterizing them as input/output relations, and stressed the political realities which often carry more weight than "rational" management techniques in practical dealings among organizations. A lively question period ensued.

During the lunch break, visitors were treated to tours of the remodeled library building, which features beautiful vistas, practical facilities, plenty of cozy spaces for study, and room for expansion.

The afternoon's program featured a panel of Minnesota librarians: Michael Kathman, Allen Dollerschell, Valera Rohrer, and Darrel Meinke, who presented some thought-provoking ideas for everyone to take back, including:

- the need for libraries to rise above competition 
among their institutions;

- new professionals are not ready to work on their first day on the job-how do we train them?

- recruitment potentials among rural junior college librarians;

-the assertion that the for-profit sector will pay for information and will make contributions if approached.

Illinois, November 2. The suburban train carried me from Chicago to Glen Ellyn to attend the Fall Conference of the Illinois Chapter (IACRL) at the College of DuPage, a very large community college serving the residents of DuPage County.

The full-day meeting began with my talk on organizational change. I described organizations as having life cycles and pictured change as equivalent to growth. After noting some of the most significant changing trends in higher education and their impact on libraries, I spoke about the way in which organizations (among them libraries) deal with change in the external environment via the techniques of differentiation and integration.

Describing the way in which libraries apply these concepts led to an examination of conflict and its resolution in the academic library, and to a presentation on open communication as a strategy for reducing resistance to change.

The day continued with sessions on funding, addressed by Ted Welch, Northern Illinois University, and Ken Peterson, Southern Illinois University, as well as innovative solutions to cutbacks, with speakers Donna Goehner, Western Illinois University, Ruth McBride, University of Illinois, Urbana, and Darrell Jenkins, Southern Illinois University. After lunch, there was a business meeting, followed by further small group sessions: one on the paraprofessional's role and the other on group dynamics in maintaining quality services, including papers by John Tyson, Northern Illinois University, and Karen Bingham, University of Illinois, Urbana.

The closing session was addressed by George F. Gruendel, of the management faculty at Sangamon State University. His topic was "Maintaining Quality Worklife in Uncertain Times."

Both of the chapters presented programs enriched by outside speakers, but gave their own members an important opportunity to make presentations to their colleagues at the local level -an invaluable experience for encouraging members' professional development.-JoAn Segal, ACRL Executive Director.

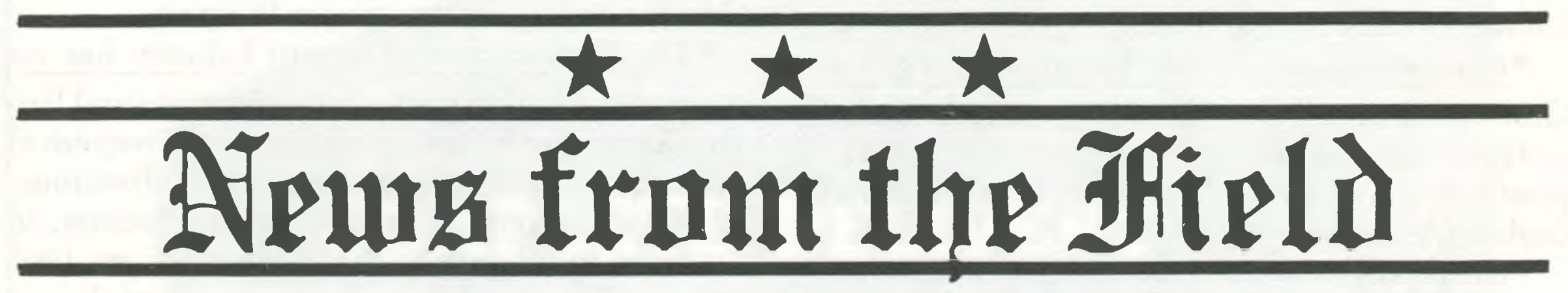

\section{Acquisitions}

- Iowa State University's Archives of American Agriculture, Ames, has received the papers of Roswell Garst, a friend of Henry A. Wallace and an ardent advocate of hybrid corn. Garst spent considerable time in Russia at the invitation of Soviet Premier Nikita Khruschev and encouraged improved trade relations with Eastern Europe. The Archives, recently established by Iowa State's Parks Library and located in Special Collections, offers many agriculture-oriented manuscript collections for scholarly use, especially the papers of individuals prominent in American agriculture.

- Michigan State University Libraries, East Lansing, has received a collection of rare cookery books assembled by the late Beatrice V. Grant, professor of foods and nutrition at MSU. Included are about 50 works on cookery and related subjects. Most were published in the 18th and 19th centuries, but a number of 17 th-century works and a few from the 20th century, including bibliographic tools, are included. Of particular interest is a French work on candy making, La Cannameliste
Française, ou nouvelle instructions por ceux qui désirent d'apprendre l'office..., published at Nancy in 1751. Its plates offer splendid depictions of 18th-century tableware. Among American works in the collection, the most interesting is an early work by an American black author, The Hotel Keeper's, Head-Waiter's and Housekeeper's Guide, written by Tunis Campbell and published in Boston in 1848.

- The University of Toronto Library held a ceremony October 5 to mark the official deposit of the Millenium Collection of 21 Old Ukrainian books. Purchase of this invaluable collection of 17 th and 18th-century Ukrainian titles from the estate of Paul Fekula, a leading North American book collector, was made possible through funds obtained by the Chair of Ukrainian Studies Foundation. Edward Keenan, Harvard University professor, and Edward Kasinec, chief of the Slavonic Division of the New York Public Library, were featured speakers at the presentation. An illustrated catalogue is available from the Chair of Ukrainian Studies, Paul Magocsi, at the University of Toronto. 